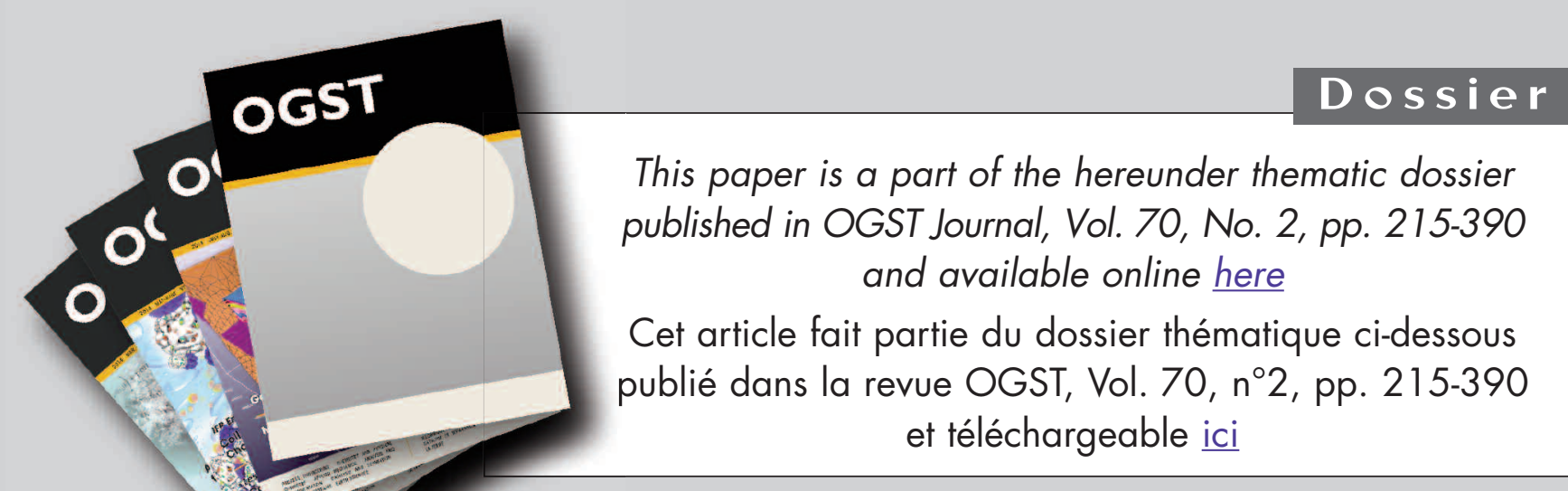

DOSSIER Edited by/Sous la direction de : B. Dewimille

Fluids-Polymers Interactions: Permeability, Durability

Interactions fluides polymères : perméabilité, durabilité

Oil \& Gas Science and Technology - Rev. IFP Energies nouvelles, Vol. 70 (2015), No. 2, pp. 215-390

Copyright (C) 2015, IFP Energies nouvelles

$215>$ Tribute to Yves Chauvin Hommage à Yves Chauvin

S. Candel and 0 . Appert

$219>$ Editorial

G. Kimmerlin

227 > Gas Permeation in Semicrystalline Polyethylene as Studied by Molecular Simulation and Elastic Model

Perméation de gaz dans le polyéthylène semi-cristallin par simulation moléculaire et modèle élastique

P. Memari, V. Lachet and B. Rousseau

237 > Reinforcement of the Gas Barrier Properties of Polyethylene and Polyamide Through the Nanocomposite Approach: Key Factors and Limitations

Renforcement des propriétés barrière aux gaz de matrices polyéthylène et polyamide par l'approche nanocomposite : facteurs clés et limitations E. Picard, J.-F. Gérard and É. Espuche

251 > Diffuso-Kinetics and Diffuso-Mechanics of Carbon Dioxide / Polyvinylidene Fluoride System under Explosive Gas Decompression: Identification of Key Diffuso-Elastic Couplings by Numerical and Experimental Confrontation

Cinétique de diffusion et comportement diffuso-mécanique du système dioxide de carbone / polyfluorure de vinylidène sous décompression explosive de gaz : identification des couplages diffuso-élastiques majeurs par confrontation numérique et expérimentale

J.-C. Grandidier, C. Baudet, S. A. E. Boyer, M.-H. Klopffer and L. Cangémi

267 > Characterization of Polymer Layered Silicate Nanocomposites by Rheology and Permeability Methods: Impact of the Interface Quality

Caractérisation de nanocomposites polymère silicate par des méthodes de rhéologie et de perméabilité : rôle de la qualité de l'interface

R. Waché, M.-H. Klopffer and S. Gonzalez

$279>$ Evaluation of Long Term Behaviour of Polymers for Offshore Oil and Gas Applications

Durabilité des polymères pour application pétrolière offshore

P.-Y. Le Gac, P. Davies and D. Choqueuse

$291>$ Development of Reactive Barrier Polymers against Corrosion for the Oil and Gas Industry: From Formulation to Qualification through the Development of Predictive Multiphysics Modeling

Développement de matériaux barrières réactifs contre la corrosion pour l'industrie pétrolière : de la formulation à la qualification industrielle en passant par le développement de modèles multiphysiques prédictifs

X. Lefebvre, D. Pasquier, S. Gonzalez, T. Epsztein, M. Chirat and F. Demanze
$305>$ Development of Innovating Materials for Distributing Mixtures of Hydrogen and Natural Gas. Study of the Barrier Properties and Durability of Polymer Pipes

Développement de nouveaux matériaux pour la distribution de mélanges de gaz naturel et d'hydrogène. Étude des propriétés barrière et de la durabilité de tubes polymères

M.-H. Klopffer, P. Berne and É. Espuche

317 > New Insights in Polymer-Biofuels Interaction

Avancées dans la compréhension des interactions polymères-biocarburants E. Richaud, F. Diouani, B. Fayolle, J. Verdu and B. Flaconneche

$335>$ Biofuels Barrier Properties of Polyamide 6 and High Density Polyethylene Propriétés barrière aux bio essences du polyamide 6 (PA6) et du polyéthylène haute densité (PEHD)

L.-A. Fillot, S. Ghiringhelli, C. Prebet and S. Rossi

353 > Permeability of EVOH Barrier Material used in Automotive Applications: Metrology Development for Model Fuel Mixtures

Perméabilité d'un matériau barrière EVOH utilisé dans des applications automobiles : développement métrologique pour des mélanges modèles de carburants

J. Zhao, C. Kanaan, R. Clément, B. Brulé, H. Lenda and A. Jonquières

367 > Effects of Thermal Treatment and Physical Aging on the Gas Transport Properties in Matrimid ${ }^{\circledR}$

Les effets du traitement thermique et du vieillissement physique sur les caractéristiques du transport au gaz dans le Matrimid ${ }^{\circledR}$

L. Ansaloni, M. Minelli, M. Giacinti Baschetti and G. C. Sarti

381 > Separation of Binary Mixtures of Propylene and Propane by Facilitated Transport through Silver Incorporated Poly(Ether-Block-Amide) Membranes Séparation de mélanges binaires de propylène et de propane par transport au travers des membranes de poly(éther-blocamide) incorporant de l'argent R. Surya Murali, K. Yamuna Rani, T. Sankarshana, A. F. Ismail and S. Sridhar 


\title{
Characterization of Polymer Layered Silicate Nanocomposites by Rheology and Permeability Methods: Impact of the Interface Quality
}

\author{
Rémi Waché, Marie-Hélène Klopffer* and Serge Gonzalez \\ IFP Energies nouvelles, 1-4 avenue de Bois-Préau, 92852 Rueil-Malmaison - France \\ e-mail: remi_wache@hotmail.com - marie-helene.klopffer@ifpen.fr -serge.gonzalez@ifpen.fr \\ * Corresponding author
}

\begin{abstract}
Polymer clay nanocomposites are mostly described as materials with improved properties. However, many studies are not concluding about the possible benefits. This work reports permeability measurements on different polyolefins nanocomposites. Clay exfoliation has been proved by various techniques. Unfortunately, the nanocomposite does not exhibit good barrier properties. Hence, permeability coefficients were found to increase. A poor quality of the interface between filler and medium is likely to be responsible for this degradation. Insufficient interactions between silicate layers and the surrounding polymer lead to preferential pathways for diffusion. Organoclay exfoliation does not necessarily lead to better barrier properties. A good quality of the interface between polymer and filler is required to reach a high performance level. The standard techniques used to characterize exfoliation degree do not permit to highlight this kind of phenomena.
\end{abstract}

Résumé - Caractérisation de nanocomposites polymère silicate par des méthodes de rhéologie et de perméabilité : rôle de la qualité de l'interface - Les nanocomposites polymère argile sont généralement décrits comme des matériaux aux propriétés améliorées. Cependant de nombreuses études ne sont pas forcément concluantes quant aux bénéfices attendus. Le présent travail rapporte des mesures de perméabilité sur différents nanocomposites à matrice polyoléfine. L'exfoliation de l'argile a été établie grâce à diverses techniques. Malheureusement les nanocomposites ne présentent pas de meilleures propriétés barrière. Plus spécifiquement une augmentation des coefficients de perméabilité a été constatée. Une mauvaise qualité de l'interface entre l'argile et la matrice est probablement responsable de cette dégradation. Une interaction insuffisante entre les feuillets de silicate et le polymère les entourant entraine la formation de chemins préférentiels de diffusion. L'exfoliation d'argile organophile n'est donc pas suffisante pour conduire à l'obtention de meilleures propriétés barrière. Une bonne qualité de l'interface entre le polymère et la charge est nécessaire pour atteindre de bonnes performances. Les techniques classiques qui caractérisent l'exfoliation ne permettent pas de mettre en avant ce type de phénomène. 


\section{INTRODUCTION}

Many current studies deal with the enhancement of physical properties that are achieved with nanocomposites compared to their neat matrix or to conventionally filled polymers systems [1-9]. Nanocomposites are composites with at least one fillers dimension in the nanometer range. Smectites are swelling clays made of stacked platelets of one nanometer thick each. Hence, they constitute an ideal filler for the synthesis of nanocomposite, requiring the chains of polymer to intercalate and swell the clay layers. An organic treatment, where the alkaline cations initially present are exchanged with alkylammoniums, is often preferred especially for unpolar polymer matrices. The major interest of nanocomposites stands in the material properties improvement at low clay loading because interactions are more numerous [1, 4-15]. It is generally admitted that, for a given filler fraction, the smaller the filler is, the larger the interactions are. So, exfoliation of the clay platelets in the polymer matrix is the key parameter which will greatly modify the properties. Therefore, many publications focused on the compatibility improvement between the filler and the matrix. The influence of the type of cations surrounding the platelets together with the cationic exchange rate has been widely documented [16-29]. For certain polymers, the introduction of a compatibilizer was found to be the successful way to separate the clay platelets in the matrix. For instance, polypropylene grafted maleic anhydride has been quickly identified as a selected choice to achieve exfoliation in polypropylene [30, 31]. The systematic influence of different compatibilizers has been later studied in various polymer matrices [32-46]. However, a too high affinity between the polymer and the clay does not lead to the best exfoliated state due to a packing effect [47-51]. Still, the microstructure is commonly seen as the Grail for the enhancement of the properties, with the shortcut that an exfoliated state can be only possible with a good interface between the polymer and the clay. In this study, an important degradation of some properties has been obtained while the microstructure exhibits a good exfoliation degree. The aim of this paper is to understand the mechanisms of such undesirable phenomena.

In the oil and gas industry, polymer materials offer good barrier properties relevant for many applications such as protective coatings, selective barriers for the separation of gases etc. In the case of pipelines for underwater transport of crude oil, leak-proof sealing for the transported fluids and protection from the external environment, are provided by polymer sheaths. These polymers are exposed to different gases under extreme conditions of temperature and pressure (up to $130^{\circ} \mathrm{C}$ and up to 500 bar) [52, 53]. In the automotive industry, fuel systems (tanks, pipes etc) are often made of polymers and their permeability coefficients to small molecules, which are present in typical gasoline compositions, are also critical.

The incorporation of platelet shape nanofillers has been investigated in order to improve the performances of such materials. Penetrant transport through a polymer membrane can be defined as the property of this material to be penetrated and crossed by molecules [54-57]. It is described by a solution-diffusion mechanism. The permeability coefficient, noted $P$, is, by definition, the product of the solubility coefficient, $S$, by the diffusion coefficient, $D$ :

$$
P=D \times S
$$

$D$ is a kinetic term that reflects the dynamics of the penetrant in the polymer phase, whereas the solubility coefficient has a thermodynamic origin and depends on the penetrant-polymer interactions. These transport parameters are dependent on the characteristics of the membrane material and of the fluids [55-62]. Due to their morphology, the case of semicrystalline polymers is particular. Indeed, studies have shown that the sorption and diffusion phenomena took place exclusively in the amorphous phase of the polymer and not in its crystalline zones. Most of the existing models are based on the two-phase model proposed and developed by Michaels and Bixler [63, 64] and Michaels and Parker [65] in which a semicrystalline polymer is represented by a mixture of crystallites and amorphous domains. The crystalline zones act as excluded volumes for the sorption process and are impermeable barriers for the diffusion process. Indeed, this dispersed crystalline phase presents a resistance to the permeant passage and then contributes to the increase of the effective path length of diffusion. The tortuosity factor characterizes the more tortuous pathway that a diffusing molecule must take in a semicrystalline polymer to pass round impenetrable crystalline zones. It is a geometrical term which depends on the crystallites anisotropy degree, the degree of crystallinity and hence, the thermal history. Moreover, the existence of the crystalline zones does not seem to influence the sorption mode in the amorphous phase.

To describe the permeability in filled polymers, the same approach has been considered and the simplest model, developed by Nielsen [66], is based on tortuosity effects. The relative permeability is given by the following expression:

$$
P_{r e l}=\frac{P_{n c}}{P_{p}}=\frac{1-\varphi_{c}}{\tau}
$$

where $P_{n c}$ is the permeability coefficient of the polymersilicate nanocomposite and $P_{p}$ that of the pure polymer, 
$\varphi_{c}$ represents the volume fraction of clay and $\tau$, the tortuosity factor is expressed by:

$$
\tau=1+\frac{L}{2 W} \varphi_{c}
$$

where $L$ and $W$ are respectively the filler length and its width. The model developed by Nielsen [66] is often referred in the community for its simplicity. However, its demonstration suffers from physical coherence as the development should have been carried out in two dimensions instead of only one. This has been modified by Lape et al. [67] and by Waché [68] in 2004, who took into account the area of the platelets, leading to a factor 3 instead of the 2 in the denominator. Many different approaches have been developed since to simulate the permeability of nanocomposites, all leading to expressions explaining a decrease of the permeability [69-76]. The second part of Nielsen's publication, which adds an interphase between the filler and the matrix is often forgotten by the community, probably because of its difficulty to evaluate experimentally the different parameters of this zone. Based on interfacial effect, we suggested previously a more simple tortuous model able to support increase as well as decrease in permeability [68].

Therefore, the presence of impermeable particles within a diffusive medium lowers the overall rate of transport. For instance, a decrease in the coefficient of permeability has been many times reported $[11,32,71$, 77-85]. This enhancement of the barrier properties has been explained through this tortuous effect because the layered silicates present a very high aspect ratio [66, 70, 74-76, 86, 87]. In this case, exfoliation largely affects the apparent shape factor of the particles.

The aim of this work is to show that exfoliation of the clay doesn't necessarily lead to the enhancement of all the properties and especially the barrier properties which are closely related to the quality of the interface [68]. In the past recent years, different studies have revealed that the permeability of nanocomposites is a lot more complex that a simple tortuosity model. Especially in polyolefines, a decrease of the barrier properties is sometimes reported [68, 88-90]. Hence, the relative barrier properties have been found to depend either on the permeant molecules [39, 91], or the cationic exchange $[92,93]$, or the clay concentration in an unexpected way $[68,91,94,95]$.

\section{EXPERIMENTAL}

\subsection{Materials}

Medium density polyethylene denoted PE3802 $\left(M_{w}=175000 \mathrm{~g} \cdot \mathrm{mol}^{-1}\right.$; crystallinity degree of $\left.55 \%\right)$ and a polyethylene grafted maleic anhydride with less than $1 \%$ in weight of maleic anhydride, Orevac 18302, (PEgMA) provided by Arkema were used in this study.

The filler is an organophilic montmorillonite, namely the Cloisite 20A supplied by Chimilab Essor. The cation present in the clay interlayer is a dimethylditallowammonium. The Cationic Exchange Capacity (CEC) is 0.93 meq. $\mathrm{g}^{-1}$ clay and the exchange ratio is around 1 . The clay interlayer distance $d_{001}$ is about $25.5 \AA$.

Polymer and clay were dry blended before mixing in a Haake Rheocord at $135^{\circ} \mathrm{C}, 100 \mathrm{rpm}$ during 12 minutes. Sheets of $1 \mathrm{~mm}$ thick were then molded by compression using a Darragon press at $170^{\circ} \mathrm{C}$ and $107 \mathrm{~Pa}$. Blends based on PE/PEgMA/Cloisite 20A but also on PEgMA/Cloisite 20A were considered. The grafted PE was studied as a compatibilizer. The weight fraction of clay in the blends was varied from 2 to $40 \mathrm{wt} \%$.

\subsection{Characterization}

Nanostructure investigation was conducted using X-Ray Diffraction (XRD) measurements and Transmission Electron Microscopy (TEM). The XRD measurements were performed on a X'Pert Philips diffractometer with $\mathrm{Cu} \mathrm{K} \mathrm{K}_{\alpha}$ radiation generated at $35 \mathrm{kV}$ and $35 \mathrm{~mA}$. All samples were analyzed in a reflection mode as the clay layers were preferentially orientated parallel to the mould surface. Transmission electronic microscopy was conducted on a Tecnai apparatus operating at $120 \mathrm{kV}$. Samples were ultramicrotomed under cryogenic conditions. Viscoelastic properties have been evaluated on a $\mathrm{RDA}_{2}$ rheometer at $170^{\circ} \mathrm{C}$ under $\mathrm{N}_{2}$. Frequency response was recorded from 0.01 to $200 \mathrm{rad}^{-\mathrm{s}^{-1}}$ for a $4 \%$ deformation (in the linear viscoelasticity zone).

\subsection{Liquid Permeability Measurement}

All the samples needed for the permeation tests were extracted from plane sheets made by compression molding of polymer pellets. The dimensions of the polymer membranes were $1 \mathrm{~mm}$ in thickness and $60 \mathrm{~mm}$ in diameter.

The employed method allows us to determine the amount of liquid crossing the material by the weight loss of a metallic cell which contains the liquid and is closed by the polymer membrane to be studied (Fig. 1) [96-98]. In that respect, this cell is periodically weighed, once a day, on a precision balance to ascertain the global weight loss of the assembly. All the measurements were conducted at $60^{\circ} \mathrm{C}$ using toluene as diffusive molecules. Figure 2 represents the theoretical curve of weight loss according to time obtained for one polymer. This plot can be divided into two parts. In the first region, called the transient state, the transfer of matter by diffusion is 
nonzero and the penetrant concentration is a function of position and time. The second region, called the steady state, corresponds to a constant flux of molecules through the membrane and to a concentration that does not vary with time. By assuming that Fick's first and second laws are obeyed, one may determine the permeability coefficient, $P$, at a given temperature, from the slope of the straight line in the steady state, that is when the weight loss is constant. Thus, $P$ is given by the following relation:

$$
P=\frac{\Delta m}{t} \times \frac{l}{A}
$$

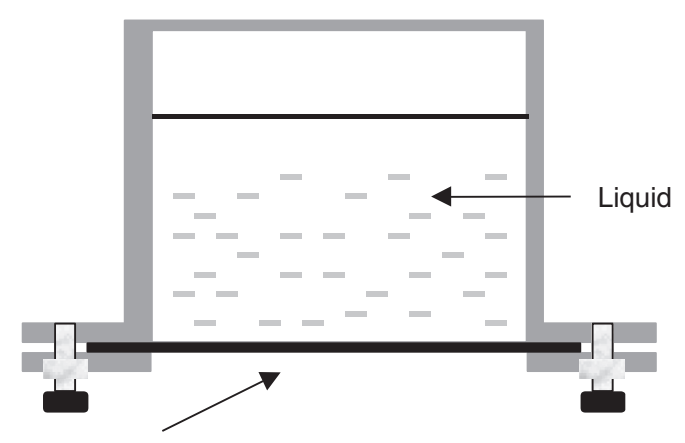

Polymer membrane

\section{Figure 1}

Schematic of a liquid permeation cell. (Reproduced from [97]) .

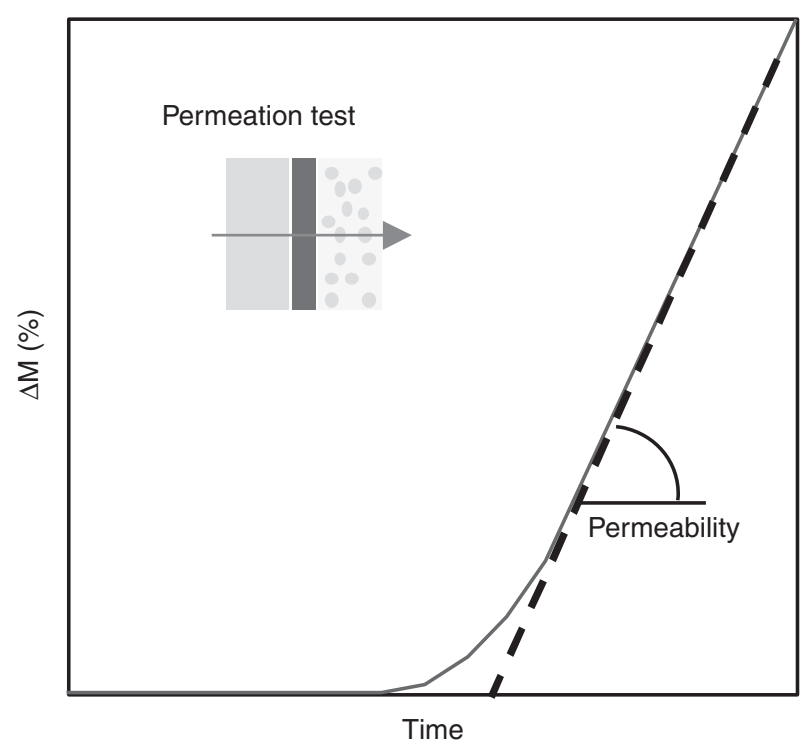

Figure 2

Theoretical curve of a liquid permeation experiment through one polymer at a given temperature. where $l$ is the membrane thickness (cm), $A$ the diffusion area $\left(\mathrm{cm}^{2}\right)$ and $\Delta m / t$ the slope of the straight line in steady state $\left(\mathrm{g} . \mathrm{s}^{-1}\right)$. So, $P$ can be expressed in $\mathrm{g} \cdot \mathrm{cm}^{-1} \cdot \mathrm{s}^{-1}$.

\section{RESULTS AND DISCUSSION}

The first formulations have been manufactured with PE and Cloisite 20A. XRD analysis reveals that there is neither intercalation nor exfoliation. The clay is always stacked in aggregates of microscopic size. The filled material is a conventional composite. Figure 3 represents the evolution of the complex viscosity versus the solicitation frequency for $\mathrm{PE} /$ Cloisite $20 \mathrm{~A}$ systems at different organoclay loadings. This figure shows that up to $15 \mathrm{wt} \%$ of organoclay, there is no real modification of the polymer behavior. For higher clay fraction, the evolution is different and there is no visible plateau for the viscosity.

From the complex viscosities, Newtonian viscosities have been estimated using a 4 parameters Carreau model. They have been normalised to that of the matrix and their evolutions with filler fraction are reported in Figure 4. A large increase appears for a critical fraction of $\phi_{\mathrm{c}}=0.075$. This change arises from the fact that each particle could no more freely rotate without interacting with its neighbours. It closely depends on the shape factor $\alpha$ of the particle. By assuming the volume swept by each particle to be related to the percolation fraction of spheres in a cubic central faces network, it is thus possible to obtain an approximation of the shape factor $\alpha$ as a function of this critical fraction $\phi_{c}$ :

$$
\phi_{c}=\frac{\pi \alpha^{2}}{2 \sqrt{2}\left(1+\alpha^{2}\right)^{\frac{3}{2}}}
$$

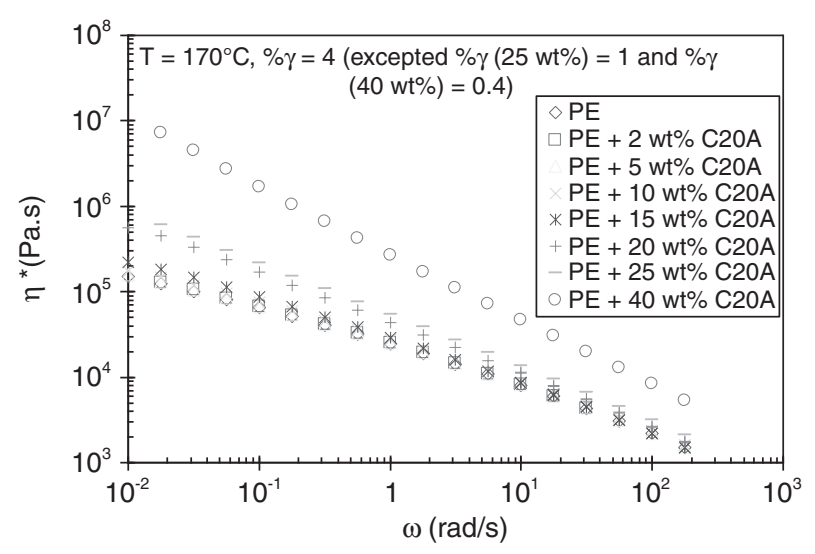

Figure 3

Evolution of the complex viscosity of PE/Cloisite 20A samples as a function of the frequency for different clay loadings. The temperature was $170^{\circ} \mathrm{C}$ and the deformation was chosen to be in the linear viscoelasticity zone. 


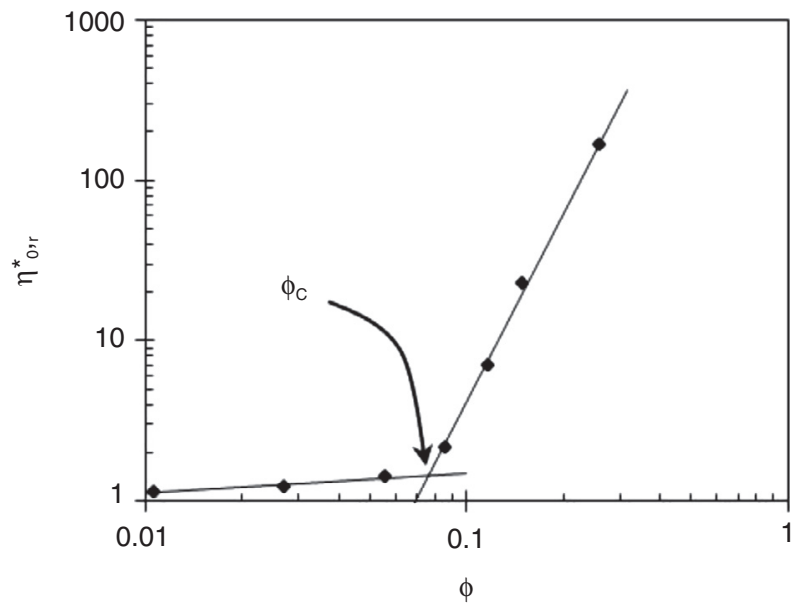

Figure 4

Evolution of the relative Newtonian viscosities with clay concentration in PE nanocomposite.

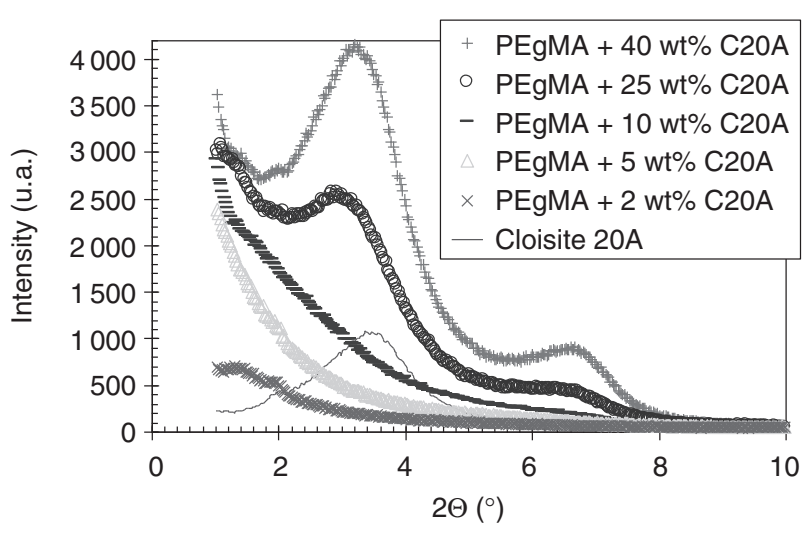

Figure 5

Influence of the clay loading on X-Ray diffraction spectra of PEgMA/Cloisite 20A mixtures.

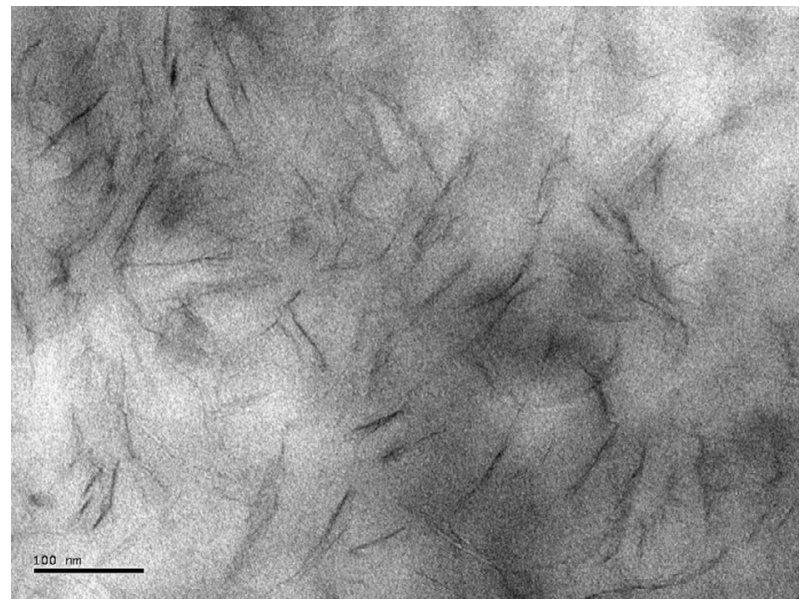

Figure 6

TEM image of the mixture PEgMA $+5 \mathrm{wt} \%$ Cloisite 20A.

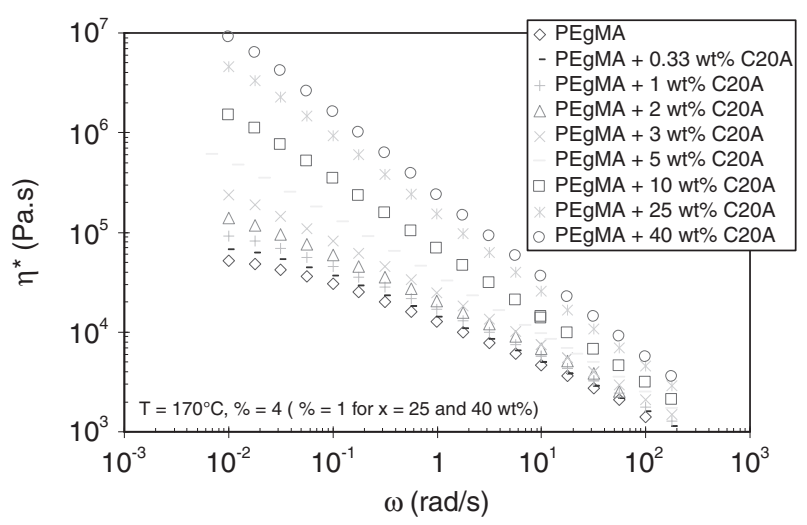

Figure 7

Complex viscosity of PEgMA/Cloisite 20A samples versus the pulsation at different clay loadings. The temperature was $170^{\circ} \mathrm{C}$ and the deformation was chosen to be in the linear viscoelasticity zone.
This leads to $\alpha=14$.

As neither intercalation nor exfoliation was achieved with PE and Cloisite systems, it was decided to use a compatibilizer such as PEgMA and the same methodology was applied to the PEgMA/Cloisite 20A samples [99].

X-Ray Diffraction spectra corresponding to the PEgMA/clay mixtures are shown in Figure 5. Up to a critical fraction of $10 \mathrm{wt} \%$ organoclay, there is no diffraction peak. This indicates an exfoliated state of the clay. At higher clay loading a diffraction peak reappears, only an intercalation of few Angstrom is obtained. The clay partially reaggregates because there is no more space in the polymer phase. Those formulations have a mixed intercalated/exfoliated structure.

The structures presumed via XRD measurements were confirmed with TEM observations of the samples. It has been checked by transmission electron microscopy that the structure is well exfoliated for $5 \mathrm{wt} \%$ clay [100]. Indeed, in Figure 6, individual dark lines (silicate layers) are homogenously dispersed in the polymer matrix.

The good degree of exfoliation can also be detected by using viscoelastic measurements because the viscosity exhibits a large increase at even very low clay loading (Fig. 7). This is completely different from the previous system PE/organoclay. As the clay fraction increases, 


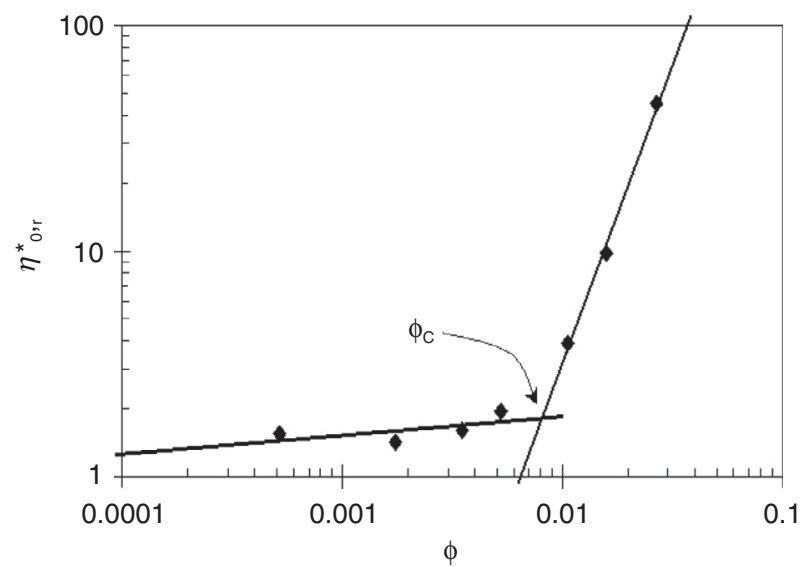

Figure 8

Evolution of the relative Newtonian viscosities with clay concentration in PEgMA.

the Newtonian plateau increases and then disappears all over the studied frequency range. The clay content corresponding to the behaviour change is around $3 \mathrm{wt} \%$ compared to $20 \mathrm{wt} \%$ in the case of a PE matrix.

The exfoliation can be identified by a modification of the properties which appears at a clay loading much lower than for the conventional composite. The volume excluded is considerably higher because the shape factor of the platelets is bigger than that of the aggregates. In Figure 8 , the critical fraction $\phi_{c}$ is only 0.008 for the PEgMA matrix which represents a shape factor $\alpha$ of about 131. The basal extension of layers has been estimated to $600 \mathrm{~nm}$ using granulometry results. This means that the number of layers per stacking is around 17 in the PE matrix against only 2 in the PEgMA matrix. The maleic anhydride groups give to the polymer chains a polarity sufficient to intercalate the clay layers and exfoliate them around the matrix.

The last step consisted in using PEgMA as a compatibilizer between the PE chains and the organoclay and thus, in studying the morphology and the properties of various ternary mixtures PE/PEgMA/Cloisite 20A. Exfoliation of the clay in such a modified PE matrix is then expected. As can be seen from Figure 9, when the PEgMA loading increases, the Bragg peak position progressively moves on lower angles and its intensity decreases, meaning that the average distance between clay layers growths and that the average number of platelets per stacking decreases. At a weight fraction of $20 \mathrm{wt} \%$ of compatibilizing agent, there is no more well defined diffraction peak meaning that the clay layers

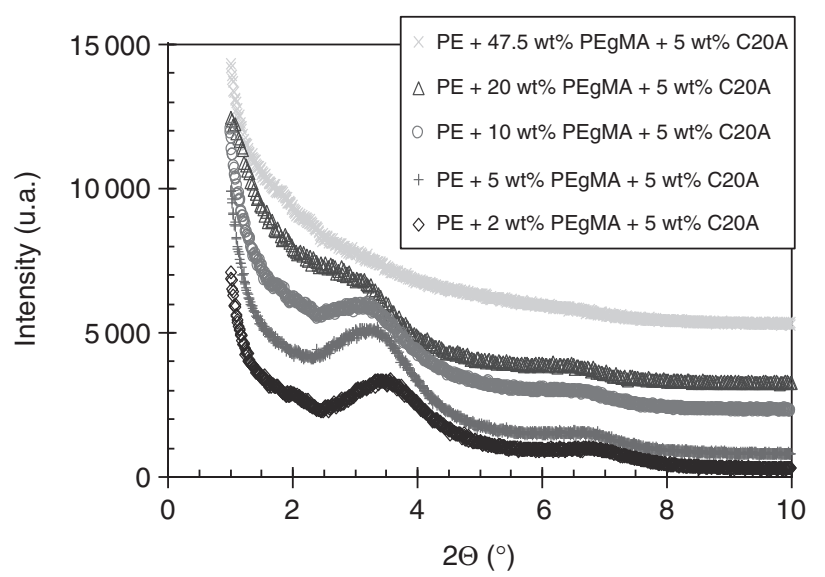

Figure 9

Influence of the compatibilizer loading on X-Ray diffraction spectra of PE/PEgMA/Cloisite 20A mixtures.

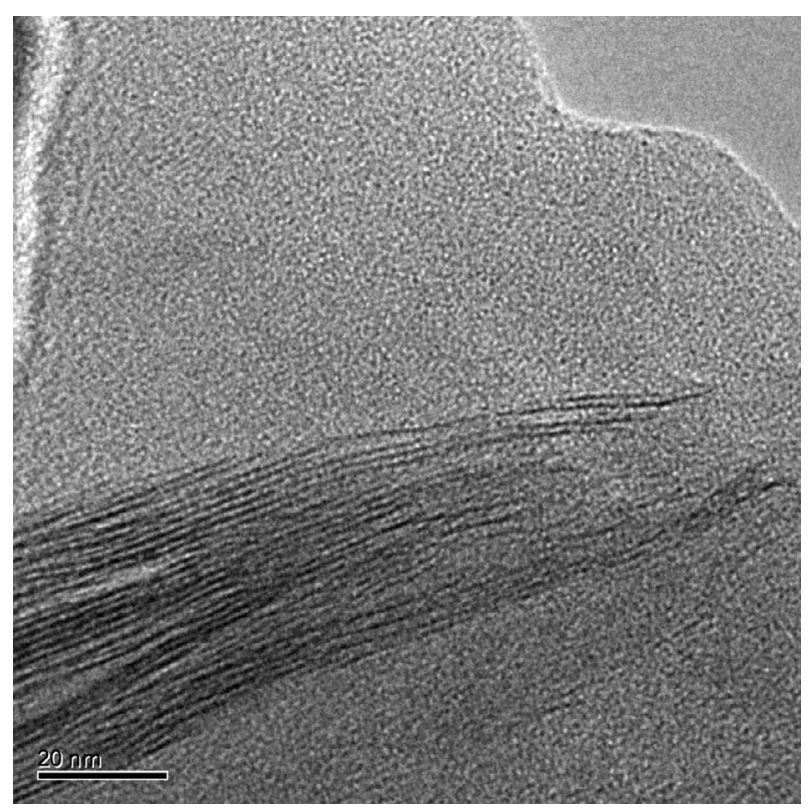

Figure 10

TEM image of the mixture $90 \mathrm{wt} \% \mathrm{PE}+5 \mathrm{wt} \%$ PEgMA $+5 \mathrm{wt} \%$ Cloisite $20 \mathrm{~A}$.

are well separated and distributed in the compatibilized matrix. The structure of these samples is partially exfoliated. In transmission electronic microscopy this is confirmed by the presence of both single layers and stacking of about ten layers (Fig. 10). The increase of the viscoelastic properties is not presented here but corresponds to an intermediate behaviour relative to $\mathrm{PE}$ and to PEgMA cases. 
TABLE 1

Toluene permeation results obtained at $60^{\circ} \mathrm{C}$ for the PEgMA/Cloisite 20A mixtures for different clay amounts

\begin{tabular}{c|c|c|c|c|c|c}
\hline Clay weight fraction (\%) & 0 & 2 & 5 & 10 & 25 & 40 \\
\hline Permeability coefficient $\left(10^{-7} \mathrm{~g} \cdot \mathrm{cm}^{-1} \cdot \mathrm{s}^{-1}\right)$ & 9.20 & 8.40 & 12.3 & 9.10 & 7.98 & 5.94 \\
\hline
\end{tabular}

The ternary blending corresponding to $75 \%$ PE- $20 \%$ PEgMA-5\% Cloisite 20A has been chosen for the permeation tests with toluene at $60^{\circ} \mathrm{C}$. The measured permeability coefficient for this nanocomposite was $2.22 \times 10^{-7}$ g.cm ${ }^{-1} \cdot \mathrm{s}^{-1}$. In order to evaluate the effect of the clay on the barrier properties, the same permeation measurements have been performed on an unfilled reference. In the case of the previous ternary mixture, the reference matrix is made of $79 \%$ of $\mathrm{PE}$ and $21 \%$ of PEgMA. The measured permeability coefficient of toluene at $60^{\circ} \mathrm{C}$ through that system was $1.42 \times 10^{-7} \mathrm{~g} . \mathrm{cm}^{-1} . \mathrm{s}^{-1}$. Thus, the permeability is higher for the nanocomposite than for its neat matrix. This higher value cannot be attributed to the presence of shorter chains such as PEgMA. Indeed, by considering the system $79 \%$ PE-21\% PEgMA as the reference matrix, the effect of these more mobile chains has already been taken into account. It has also been checked by differential scanning calorimetry that the degree of crystallinity was not changed due to the presence of maleated chains of polyethylene.

As this increase of the permeability coefficient was quite surprising, the barrier properties of the binary mixtures PEgMA-Cloisite 20A have been also investigated. The experimental values of toluene permeation for the different PEgMA-Cloisite 20A nanocomposites at $60^{\circ} \mathrm{C}$ are summarized in Table 1 . The relative permeability coefficients have been calculated by using Equation (2) and are plotted against the organophilic clay weight fraction in Figure 11. The resulting plot exhibits an unusual behaviour. Indeed, the barrier properties are not systematically enhanced as it is commonly mentioned in the literature $[32,71,79-81,84,85]$. The permeability of the sample with $5 \mathrm{wt} \%$ of Cloisite even increases compared to the PEgMA matrix although an exfoliated state has been reached. The relative permeability predicted by Nielsen's modified model is also plotted in Figure 11 for different shape factors and it is impossible to find an agreement between the model and the data. Whatever the state of exfoliation of the clay platelets or the orientation of the silicate layers relative to the diffusion direction are, a decrease should have been obtained. Thus exfoliation is not the only factor governing the reduction in permeability.

Several assumptions were taken into account to explain the higher permeability value in the presence of

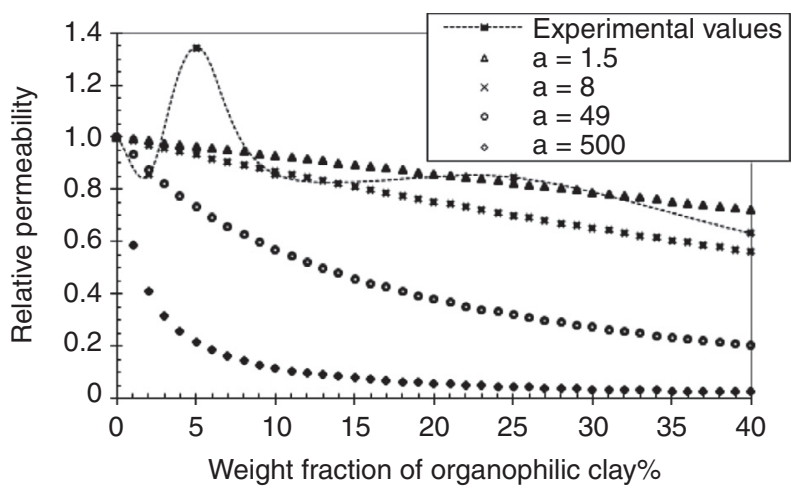

Figure 11

Experimental relative permeability in PEgMA compared to the Nielsen's model for different shape factors $a$.

the clay layers [68]. As previously demonstrated, exfoliation and orientation of the platelets cannot be responsible. The second point concerns the crystallinity degree of the resulting nanocomposite, $\chi_{c}$, which could have varied. But DSC (Differential Scanning Calorimetry) measurements do not reveal change of $\chi_{\mathrm{c}}$ due to blending of the polymer with the clay. X-ray measurements data on higher angles confirm this point as no change in the crystal form was noticed.

Another explanation could be the existence of particular interactions between the clay and the diffusing molecules. Some sorption tests with different chemical penetrants were carried out in order to evaluate the solubility coefficient of the penetrant in the nanocomposite revealing only a moderate increase of the solubility insufficient to explain alone the increase of the nanocomposite permeability.

Therefore, we suggest the existence of preferential ways for diffusion inside the nanocomposite. The diffusion coefficients $D$ have been extracted from the permeation measurements $[68,100]$. It appears that $D$ is higher in the nanocomposite which means a greater mobility of the diffusing molecules or a lower resistance of the nanocomposite to the transport of small molecules. It is reasonable to propose that this additional mobility is the consequence of either the presence of nano-voids in the polymer, or the poor quality interface between the clay 


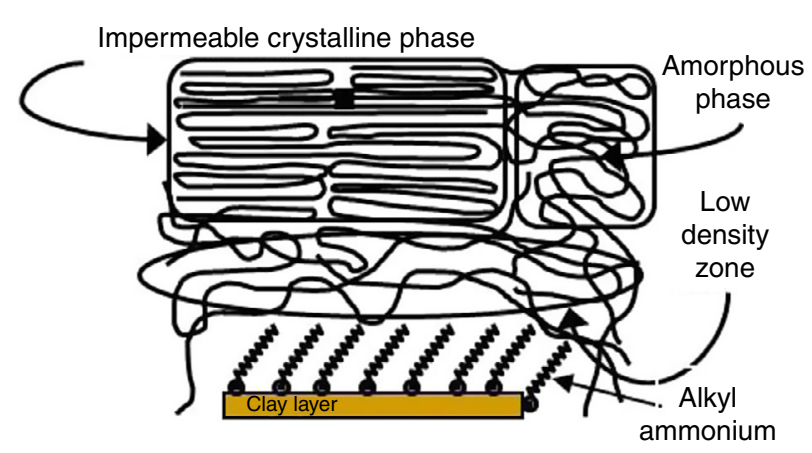

Figure 12

Schematic representation of the interfacial zone in the PEgMA/5\% Cloisite 20A mixture.

sheets and the polymer [101]. The alkyl ammonium promoting the clay exfoliation may also perturb the interaction between the polymer and the nanoplatelet by creating a localized weak zone.

At room temperature, the considered polymer is far above its glass transition, therefore, all stress due to the crystallisation should have been relaxed. So the most relevant hypothesis is that, due to the non-polar character of the modified polyethylene backbone, the interactions between PEgMA and the silicate layers are not sufficient to have a good contact between those two parts. In fact, we suggest that the interface close to the clay layer and the PEgMA corresponds to lower density zones than in the bulk polymer, acting as preferential pathways for diffusion of the species (Fig. 12) and lead, as a consequence, to higher permeability coefficients. This interpretation is supported by the fact that measurements performed on a polar system such as polyamide with an exfoliated clay exhibit an improvement of the barrier properties (decrease of the permeability and diffusion coefficients) $[68,83]$. Moreover, in this case, some modifications in the crystallites have been observed (such as the removal of the long period by SAXS measurements and the appearance of the $\gamma$ crystalline phase instead of the $\alpha$ one), which are not sufficient to explain the decrease of the diffusion, but ascertain that the clay layers have an influence on the nucleation process. Confronting this idea of lower density zones, or greater mobility, in simple equations to simulate the barrier properties by considering a higher value of the velocity of the diffusing specie in the neighborhood of the clay, has given promising results [68].

To conclude on barrier properties, it has been shown that, in opposite to what is usually admitted, the transport parameters of the nanocomposites have been deteriorated. It has been suggested that the polymer chains may organize themselves near the clay layers in a low density way. Those domains could accelerate the diffusion and explain the obtained results.

\section{CONCLUSIONS}

The exfoliation of the clay has been proven by various techniques such as X-Ray Diffraction, Transmission Electronic Microscopy in a PEgMA matrix but also in a compatibilized polyethylene matrix. The barrier properties to toluene have been characterized. Unfortunately, the nanocomposites do not exhibit good barrier properties. Several assumptions have been discussed to explain this phenomenon. A poor quality of the interface between the filler and the medium will induce a lower resistance for fluid transport and is likely to be responsible for those results. A schematic representation of the system has been proposed by considering that some regions with lower density or higher mobility may exist in the neighboring of the fillers. Besides, it reveals that permeability measurements could be a very useful tool to test the interface quality.

In polyethylene systems, the exfoliation of the silicate layers does not lead necessarily to better barrier properties. A good interface between the clay and the polymer matrix is required to reach a high performance level. The control and improvement of interfacial resistance is a keypoint for the development of new promising materials with enhanced barrier and mechanical properties.

\section{REFERENCES}

1 Fukushima Y., Inagaki S. (1987) Synthesis of an intercalated compound of montmorillonite and 6-polyamide, Journal of Inclusion Phenomena 5, 473-482.

2 Fukushima Y., Okada A., Kawasumi M., Kurauchi T., Kamigaito O. (1988) Swelling behaviour of montmorillonite by poly-6-amide, Clay Minerals 23, 27-34.

3 Kojima Y., Usuki A., Kawasumi M., Okada A., Fukushima Y. (1993) Mechanical properties of nylon 6-clay hybrid, J. Mater. Res. 8, 5, 1185-1189.

4 Kojima Y., Usuki A., Kawasumi M., Okada A., Kurauchi T., Kamigaito O. (1993) Sorption of water in nylon6-clay hybrid, J. Applied Polymer Sci. 49, 11, 1259-1264.

5 Okada A., Kawasumi M., Kurauchi T., Kamigaito O. (1987) Synthesis and characterization of Nylon 6-Clay Hybrid, Polym. Prepr. 28, 447-448.

6 Okada A., Kawasumi M., Usuki A., Kojima Y., Kurauchi T., Kamigaito O. (1990) Nylon 6-Clay Hybrid, Mat. Res. Soc. Symp. Proc. 171, 45-50.

7 Usuki A., Kawasumi M., Kojima Y., Okada A., Kurauchi T., Kamigaito O. (1993) Swelling behavior of montmorillonite cation exchanged for $\omega$-amino acids by $\varepsilon$-caprolactam, J. Mater. Res. 8, 5, 1174-1178. 
8 Usuki A., Kojima Y., Kawasumi M., Okada A., Fukushima Y., Kurauchi T., Kamigaito O. (1993) Synthesis of nylon 6-clay hybrid, J. Mater. Res. 8, 5, 1179-1184.

9 Yano K., Usuki A., Okada A., Kurauchi T., Kamigaito O. (1991) Synthesis and properties of polyimide-clay hybrid, Polym. Prepr. 32, 65-66.

10 Lan T., Kaviratna P.D., Pinnavaia T.J. (1995) Mechanism of clay tactoid exfoliation in epoxy-clay nanocomposites, Chem. Mater. 7, 2144-2150.

11 Lan T., Kaviratna P.D., Pinnavaia T.J. (1994) On the nature of polyimide-clay hybrid composites, Chem. Mater. 6, $5,573-575$.

12 Pinnavaia T.J., Beall G.W. (2000) Polymer-Clay Nanocomposites, John Wiley \& Sons, Chichester, UK.

13 Vaia R.A., Ishii H., Giannelis E.P. (1993) Synthesis and properties of two-dimensional nanostructures by direct intercalation of polymer melts in layered silicates, Chem. Mater. 5, 1694-1696.

14 Vaia R.A., Jandt K.D., Kramer E.J., Giannelis E.P. (1995) Kinetics of polymer melt intercalation, Macromolecules $\mathbf{2 8}$, 24, 8080-8085

15 Giannelis E.P. (1996) Polymer Layered Silicate Nanocomposites, Adv. Mater. 8, 1, 29-35.

16 Artzi N., Nir Y., Narkis M., Siegmann A. (2002) Melt blending of ethylene-vinyl alcohol copolymer/clay nanocomposites: Effect of the clay type and processing conditions, Journal of Polymer Science Part B: Polymer Physics 40, 16, 1741-1753.

17 Lee K.M., Han C.D. (2003) Rheology of organoclay nanocomposites: effects of polymer matrix/organoclay and the gallery distance of organoclay, Macromolecules 36, 19, 7165-7178.

18 Pozsgay A., Fráter T., Százdi L., Müller P., Sajó I., Pukánszky B. (2004) Gallery structure and exfoliation of organophilized montmorillonite: effect on composite properties, European Polymer Journal 40, 1, 27-36.

19 Shi H., Lan T., Pinnavaia T.J. (1996) Interfacial Effects on the Reinforcement Properties of Polymer-Organoclay Nanocomposites, Chemistry of Materials 8, 8, 1584-1587.

20 Su S., Jiang D.D., Wilkie C.A. (2004) Poly(methyl methacrylate), polypropylene and polyethylene nanocomposite formation by melt blending using novel polymericallymodified clays, Polymer Degradation and Stability 83, 2, 321-331.

21 Suh D.J., Park O.O. (2002) Nanocomposite structure depending on the degree of surface treatment of layered silicate, J. Applied Polymer Sci. 83, 2143-2147.

22 Usuki A., Kato M., Okada A., Kurauchi T. (1997) Synthesis of polypropylene-clay hybrid, J. Applied Polymer Sci. 63, 137-139.

23 Vaia R.A., Giannelis E.P. (1997) Lattice model of polymer melt intercalation in organically-modified layered silicates, Macromolecules 30, 7990-7999.

24 Vaia R.A., Giannelis E.P. (1997) Polymer melt intercalation in organically-modified layered silicates: model predictions and experiment, Macromolecules 30, 24, 8000-8009.

25 Wanjale S.D., Jog J.P. (2004) Poly(4-methyl-1-pentene)/ clay nanocomposites: Effect of organically modified layered silicates, Polymer International 53, 1, 101-105.
26 Zhang W., Chen D., Zhao Q., Fang Y. (2003) Effects of different kinds of clay and different vinyl acetate content on the morphology and properties of EVA/clay nanocomposites, Polymer 44, 26, 7953-7961.

27 Zhang Y.H., Gong K.C. (1998) Effect of quaternary ammonium-modified montmorillonites on mechanical properties of polypropylene, Mat. Res. Soc. Symp. Proc. 520, 191-195.

28 Phua S.L., Yang L., Toh C.L., Huang S., Tsakadze Z., Lau S.K., Mai Y.-W., Lu X. (2012) Reinforcement of Polyether Polyurethane with Dopamine-Modified Clay: The Role of Interfacial Hydrogen Bonding, ACS Applied Materials \& Interfaces 4, 9, 4571-4578.

29 Unnikrishnan L., Mohanty S., Nayak S.K., Ali A. (2011) Preparation and characterization of poly(methyl methacrylate)-clay nanocomposites via melt intercalation: Effect of organoclay on thermal, mechanical and flammability properties, Materials Science and Engineering: A 528, 12, 3943-3951.

30 Kato M., Usuki A., Okada A. (1997) Synthesis of polypropylene oligomer - clay intercalation compounds, Journal of Applied Polymer Science 66, 9, 1781-1785.

31 Kawasumi M., Hasegawa N., Kato M., Usuki A., Okada A. (1997) Preparation and Mechanical Properties of Polypropylene-Clay Hybrids, Macromolecules 30, 20, 63336338 .

32 Durmus A., Woo M., Kaşgöz A., Macosko C.W., Tsapatsis M. (2007) Intercalated linear low density polyethylene (LLDPE)/clay nanocomposites prepared with oxidized polyethylene as a new type compatibilizer: Structural, mechanical and barrier properties, European Polymer Journal 43, 9, 3737-3749.

33 Garcia-Lopez D., Picazo O., Merino J.C., Pastor J.M. (2003) Polypropylene-clay nanocomposites: effect of compatibilizing agents on clay dispersion, European Polymer Journal 39, 5, 945-950.

34 Gopakumar T.G., Lee J.A., Kontopoulou M., Parent J.S. (2002) Influence of clay exfoliation on the physical properties of montmorillonite/polyethylene composites, Polymer 43, 20, 5483-5491.

35 Ishida H., Campbell S., Blackwell J. (2000) General approach to nanocomposite preparation, Chem. Mater. 12, 1260-1267.

36 Koo C.M., Ham H.T., Kim S.O., Wang K.H., Chung I.J. (2002) Morphology evolution and anisotropic phase formation of the maleated polyethylene-layered silicates nanocomposites, Macromolecules 35, 13, 5116-5122.

37 Liang G., Xu J., Bao S., Xu W. (2004) Polyethylene/maleic anhydride grafted polyethylene/organic-montmorillonite nanocomposites. I. Preparation, microstructure, and mechanical properties, J. Applied Polymer Sci. 91, 6, 3974-3980.

38 Liang G., Xu J., Xu W. (2004) PE/PE-g-MAH/Org-mmt nanocomposites. II. Nonisothermal crystallisation kinetics, J. Applied Polymer Sci. 91, 5, 3054-3059.

39 Sharif-Pakdaman A., Morshedian J., Jahani Y. (2013) Effect of organoclay and silane grafting of polyethylene on morphology, barrierity, and rheological properties of HDPE/PA6 blends, Journal of Applied Polymer Science 127, 2, 1211-1220. 
40 Varela C., Rosales C., Perera R., Matos M., Poirier T., Blunda J. (2002) Use of functionalized polypropylenes in the compatibilization and dispersion of nanocomposites, Nanocomposites 2002, San Diego, US, 23-25 Sept.

41 Wang Z.M., Nakajima H., Manias E., Chung T.C. (2003) Exfoliated PP/Clay nanocomposites using ammoniumterminated PP as the organic modification for montmorillonite, Macromolecules 36, 24, 8919-8922.

42 Bagheri-Kazemabad S., Fox D., Chen Y., Geever L.M., Khavandi A., Bagheri R., Higginbotham C.L., Zhang H., Chen B. (2012) Morphology, rheology and mechanical properties of polypropylene/ethylene-octene copolymer/ clay nanocomposites: Effects of the compatibilizer, Composites Science and Technology 72, 14, 1697-1704.

43 Uribe-Calderon J., Kamal M.R. (2010) Evaluation of various Surfactants and Compatibilizers for Preparation of PS/Clay Nanocomposites by Melt Compounding, Journal of Polymer Engineering 30, 5-7, 377-412.

44 Pack S., Kashiwagi T., Cao C., Korach C.S., Lewin M., Rafailovich M.H. (2010) Role of Surface Interactions in the Synergizing Polymer/Clay Flame Retardant Properties, Macromolecules 43, 12, 5338-5351.

45 Dal Castel C., Pelegrini Jr T., Barbosa R.V., Liberman S. A., Mauler R.S. (2010) Properties of silane grafted polypropylene/montmorillonite nanocomposites, Composites Part A: Applied Science and Manufacturing 41, 2, 185-191.

46 Mainil M., Alexandre M., Monteverde F., Dubois P. (2006) Polyethylene Organo-Clay Nanocomposites: The Role of the Interface Chemistry on the Extent of Clay Intercalation/Exfoliation, Journal of Nanoscience and Nanotechnology 6, 2, 337-344.

47 Lee S.-S., Hur M.H., Yang H., Lim S., Kim J. (2006) Effect of interfacial attraction on intercalation in polymer/clay nanocomposites, Journal of Applied Polymer Science 101, 5, 2749-2753.

48 Lyatskaya Y., Balazs A.C. (1998) Modeling the Phase Behavior of Polymer-Clay Composites, Macromolecules 31, 19, 6676-6680.

49 Balazs A.C., Singh C., Zhulina E. (1998) Modeling the Interactions between Polymers and Clay Surfaces through SelfConsistent Field Theory, Macromolecules 31, 23, 8370-8381.

50 Zhulina E., Singh C., Balazs A.C. (1999) Attraction between Surfaces in a Polymer Melt Containing Telechelic Chains: Guidelines for Controlling the Surface Separation in Intercalated Polymer-Clay Composites, Langmuir 15, $11,3935-3943$.

51 Lee S.-S., Kim J. (2004) Surface modification of clay and its effect on the intercalation behavior of the polymer/clay nanocomposites, Journal of Polymer Science Part B: Polymer Physics 42, 12, 2367-2372.

52 Flaconneche B., Martin J., Klopffer M.-H. (2001) Permeability, Diffusion and Solubility of Gases in Polyethylene, Polyamide 11 and Poly (Vinylidene Fluoride), Oil \& Gas Science and Technology - Rev. IFP 56, 3, 261-278.

53 Klopffer M.-H., Flaconneche B. (2001) Transport Properdines of Gases in Polymers: Bibliographic Review, Oil \& Gas Science and Technology - Rev. IFP 56, 3, 223-244.

54 Stannett V. (1978) The transport of gases in synthetic polymeric membranes - an historic perspective, Journal of Membrane Science 3, 2, 97-115.

55 Crank J. (1975) The Mathematics of Diffusion, 2nd ed., Oxford.
56 Crank J., Park G.S. (1968) Diffusion in polymers, Academic Press, London, New York, N.Y.

57 Naylor T.V. (1989) Permeation Properties, in Comprehensive Polymer Science, Booth C. and Price C. (eds), Pergamon Press, Oxford, pp. 643-668.

58 Koros W.J., Hellums M.W. (1985) Transport Properties, in Encyclopedia of Polymer Science and Technology, John Wiley \& Sons, pp. 725-802.

59 Neogi P. (1996) Transport Phenomena in Polymer Membranes, in Diffusion in Polymers, Marcel Dekker Inc., New York, pp. 173-210.

60 Rogers C.E. (1964) Permeability and Chemical Resistance, in Engineering design for plastics, Baer E. (ed.), Reinhold, New York, pp. 609-688.

61 Rogers C.E. (1985) Permeation of gases and vapours in polymers, in Polymer permeability, Comyn J. (ed.), Elsevier Applied Science, pp. 11-73.

62 Alexander Stern S. (1994) Polymers for gas separations: the next decade, Journal of Membrane Science 94, 1, 1-65.

63 Michaels A.S., Bixler H.J. (1961) Flow of gases through polyethylene, Journal of Polymer Science 50, 413-439.

64 Michaels A.S., Bixler H.J. (1961) Solubility of gases in polyethylene, Journal of Polymer Science 50, 154, 393-412.

65 Michaels A.S., Parker R.B. (1959) Sorption and flow of gases in polyethylene, Journal of Polymer Science 41, 138, 53-71.

66 Nielsen L.E. (1967) Models for the permeability of filled polymer systems, J. Macromol. Sci. 5, A1, 929-942.

67 Lape N.K., Nuxoll E.E., Cussler E.L. (2004) Polydisperse flakes in barrier films, Journal of Membrane Science 236, 1-2, 29-37.

68 Waché R. (2004) Formulation et caractérisation de polyéthylènes chargés avec des argiles. Propriétés barrière des nanocomposites obtenus, Thèse, Université de Bretagne Occidentale, Brest.

69 Choudalakis G., Gotsis A.D. (2009) Permeability of polymer/clay nanocomposites: A review, European Polymer Journal 45, 4, 967-984.

70 Bharadwaj R.K. (2001) Modeling the barrier properties of polymer-layered silicates nanocomposites, Macromol. 34, 9189-9192.

71 Cussler E.L., Hughes S.E., Ward W.J., Aris R. (1988) Barrier membranes, Journal of Membrane Science 38, 161-174.

72 Adame D., Beall G.W. (2009) Direct measurement of the constrained polymer region in polyamide/clay nanocomposites and the implications for gas diffusion, Applied Clay Science 42, 3-4, 545-552.

73 Lu C., Mai Y.-W. (2007) Permeability modelling of polymer-layered silicate nanocomposites, Composites Science and Technology 67, 14, 2895-2902.

74 Gusev A.A., Lusti H.R. (2001) Rational design of nanocomposites for barrier applications, Adv. Mater. 13, 21, 1641-1643.

75 Fredrickson G.H., Bicerano J. (1999) Barrier properties of oriented disk composites, Journal of Chemical Physics 110, 4, 2181-2188.

76 Picard E., Vermogen A., Gérard J.F., Espuche E. (2007) Barrier properties of nylon 6-montmorillonite nanocomposite membranes prepared by melt blending: Influence of the clay content and dispersion state: Consequences on modelling, Journal of Membrane Science 292, 1-2, 133-144. 
77 Messersmith P.B., Giannelis E.P. (1995) Synthesis and barrier properties of poly(e-caprolactone)-layered silicate nanocomposites, J. Polym. Sci., Part A 33, 1047-1057.

78 Yano K., Usuki A., Okada A. (1997) Synthesis and properties of polyimide-clay hybrid films, J. Polym. Sci., Part A 35, 2289-2294.

79 Gorrasi G., Tammaro L., Tortora M., Vittoria V., Kaempfer D., Reichert P., Mülhaupt R. (2003) Transport properties of organic vapors in nanocomposites of isotactic polypropylene, J. Polym. Sci., Part B 41, 15, 1798-1805.

80 Gorrasi G., Tortora M., Vittoria V., Kaempfer D., Mülhaupt R. (2003) Transport properties of organic vapors in nanocomposites of organophilic layered silicate and syndiotactic polypropylene, Polymer 44, 3679-3685.

81 Gorrasi G., Tortora M., Vittoria V., Pollet E., Lepoittevin B., Alexandre M., Dubois P. (2003) Vapor properties of polycaprolactone montmorillonite nanocomposites: Effect of clay dispersion, Polymer 44, 8, 2271-2279.

82 Tortora M., Gorrasi G., Vittoria V., Galli G., Ritrovati S., Chiellini E. (2002) Structural characterization and transport properties of organically modified montmorillonite/ polyurethane nanocomposites, Polymer 43, 6147-6157.

83 Klopffer M.-H., Waché R., Flaconnèche B., Vinciguerra E., Gonzalez S. (2002) Polymer clay nanocomposites for the enhancement of barrier properties to organic fluids, Nanocomposites 2002, San Diego, US, 23-25 Sept.

84 Pereira de Abreu D.A., Paseiro Losada P., Angulo I., Cruz J.M. (2007) Development of new polyolefin films with nanoclays for application in food packaging, European Polymer Journal, 43, 6, 2229-2243.

85 Arunvisut S., Phummanee S., Somwangthanaroj A. (2007) Effect of clay on mechanical and gas barrier properties of blown film LDPE/clay nanocomposites, Journal of Applied Polymer Science 106, 4, 2210-2217.

86 Swain S.K., Isayev A.I. (2007) Effect of ultrasound on HDPE/clay nanocomposites: Rheology, structure and properties, Polymer 48, 1, 281-289.

87 DeRocher J.P., Gettelfinger B.T., Wang J., Nuxoll E.E., Cussler E.L. (2005) Barrier membranes with different sizes of aligned flakes, Journal of Membrane Science 254, 1-2, 21-30.

88 Hong S.-I., Rhim J.-W. (2012) Preparation and properties of melt-intercalated linear low density polyethylene/clay nanocomposite films prepared by blow extrusion, $L W T$ Food Science and Technology 48, 1, 43-51.

89 Song P.a., Yu Y., Zhang T., Fu S., Fang Z., Wu Q. (2012) Permeability, Viscoelasticity, and Flammability Performances and Their Relationship to Polymer Nanocomposites, Industrial \& Engineering Chemistry Research 51, 21, 7255-7263.

90 Picard E., Gauthier H., Gérard J.F., Espuche E. (2007) Influence of the intercalated cations on the surface energy of montmorillonites: Consequences for the morphology and gas barrier properties of polyethylene/montmorillonites nanocomposites, Journal of Colloid and Interface Science 307, 2, 364-376.
91 Alexandre B., Colasse L., Langevin D., Mederic P., Aubry T., Chappey C., Marais S. (2010) Transport mechanisms of small molecules through polyamide 12 /montmorillonite nanocomposites, J. Phys. Chem. B 114, 27, 8827-37.

92 Mittal V. (2013) Modeling and prediction of tensile modulus and oxygen permeation properties of polyethylene layered silicate nanocomposites: Factorial and mixture designs, Journal of Reinforced Plastics and Composites 32, 4, 258-272.

93 Gain O., Espuche E., Pollet E., Alexandre M., Dubois P. (2005) Gas barrier properties of poly( $\varepsilon$-caprolactone)/clay nanocomposites: Influence of the morphology and polymer/clay interactions, Journal of Polymer Science Part B: Polymer Physics 43, 2, 205-214.

94 Carrera M.C., Erdmann E., Destéfanis H.A. (2013) Barrier Properties and Structural Study of Nanocomposite of HDPE/Montmorillonite Modified with Polyvinylalcohol, Journal of Chemistry 2013, 7.

95 Monsiváis-Barrón A.J., Bonilla-Rios J., Ramos de Valle L. F., Palacios E. (2013) Oxygen permeation properties of HDPE-layered silicate nanocomposites, Polymer Bulletin 70, 3, 939-951.

96 Stannett V., Yasuda H. (1965) The Measurement of Gas and Vapor Permeation and Diffusion in Polymers, in Testing of polymers, Comyn J. (ed.), Interscience Publishers, pp. 393-418.

97 Flaconnèche B., Klopffer M.-H., Martin J., TaravelCondat C. (2001) High pressure permeation of gases in semicrystalline polymers: measurement method and experimental data, 3rd MERL Conference on Oilfield Engineering with Polymers, London, 28-29 Nov.

98 Brown R.P. (1981) Permeability, in Handbook of Plastics Tests Methods, Comyn J. (ed.), G. Godwin Limited, pp. 378-394.

99 Waché R., Klopffer M.-H., Vinciguerra E., Gonzalez S., Moan M. (2002) Formulation et caractérisation de nanocomposites à matrice polyéthylène, Matériaux 2002, Tours, France, 21-25 Oct.

100 Waché R., Klopffer M.-H., Gonzalez S., Médéric P., Moan M. (2003) Maleated polyethylene nanocomposites: influence of clay content on barrier and melt rheological properties, Eurofillers 2003, Alicante, Spain, 8-11 Sept.

101 Manninen A.R., Naguib H.E., Nawaby A.V., Day M. (2005) $\mathrm{CO}_{2}$ sorption and diffusion in polymethyl methacrylate-clay nanocomposites, Polymer Engineering \& Science 45, 7, 904-914.

Cite this article as: R. Waché, M.-H. Klopffer and S. Gonzalez (2015). Characterization of Polymer Layered Silicate Nanocomposites by Rheology and Permeability Methods: Impact of the Interface Quality, Oil Gas Sci. Technol 70, 2, $267-277$. 